\title{
WORKING ABROAD, WORKING WITH OTHERS: HOW FIRMS LEARN TO OPERATE INTERNATIONAL JOINT VENTURES
}

\author{
HARRY G. BARKEMA \\ Tilburg University \\ ODED SHENKAR \\ Tel Aviv University, University of Hawaii \\ FREEK VERMEULEN \\ JOHN H. J. BELL \\ Tilburg University
}

\begin{abstract}
Successful international joint ventures entail both learning to operate across national boundaries and learning to cooperate. Hypotheses grounded in organizational learning theory were tested with eventhistory analysis and data on 1,493 expansions of 25 large Dutch firms between 1966 and 1994. Experience with domestic joint ventures and with international wholly owned subsidiaries contributed to the longevity of international joint ventures, but prior experience with international joint ventures did not.
\end{abstract}

International joint ventures have become a prevalent mode of entry into global markets (Berg, Duncan, \& Friedman, 1982; Harrigan, 1985; Hergert \& Morris, 1988; Wysocki, 1990). Publications on the topic mostly focus on the motivations behind international joint venture formation (Buckley \& Casson, 1988; Contractor \& Lorange, 1988; Harrigan, 1985; Hennart, 1988; Hergert \& Morris, 1988; Kogut, 1988) and the conditions encouraging it (Agarwal \& Ramaswami, 1992; Gatignon \& Anderson, 1988; Gomes-Casseres, 1989; Hennart, 1991; Madhok, 1997; Stopford \& Wells, 1972). Little has been done, however, to identify the factors that underlie success and failure in such ventures; this is a remarkable omission, given their high failure rate (Chowdhury, 1992; Gomes-Casseres, 1987; Hill \& Hellriegel, 1994; Levine \& Byrne, 1986). To the extent that international joint venture failure is studied, explanations have been confined to one area, namely, lack of the skills needed to manage affiliates dispersed in unfamiliar foreign environments (Buckley \& Casson, 1988). To be successful in operating joint undertakings, however, firms also need to master sharing ownership with a partner whose interests only partially overlap with their own (Shenkar \& Zeira, 1987). tions.

We would like to thank the anonymous reviewers for their helpful comments and sugges- 
The present research examined the two sets of skills within an evolutionary perspective, to explain how firms learn to handle international joint ventures. Hypotheses were derived from organizational learning theory (Cohen \& Levinthal, 1990; Cyert \& March, 1963) to indicate learning stemming from experience with international wholly owned subsidiaries, with domestic joint ventures, and with previous international joint ventures. Data on 1,493 domestic and international expansions of 25 Dutch multinationals from 1966 to 1994 allowed for a longitudinal examination of learning paths and their implications for international joint venture longevity.

\section{THEORY AND HYPOTHESES}

According to organizational learning theory, prior learning facilitates the learning and application of new, related knowledge (Cohen \& Levinthal, $1989,1990,1994)$. This idea can be extended to include the case in which the knowledge in question is itself a set of learning skills constituting a firm's absorptive capacity. This capacity increases incrementally as a function of the previous experience of the firm and its learning processes. In the foreign entry literature, advocates of the internationalization process school, or the Uppsala stage model (Johanson \& Vahlne, 1977), have argued that firms expand slowly from their domestic bases into progressively distant areas. Experiential learning from previous entries is the driving force behind new investments (Barkema, Bell, \& Pennings, 1996; Davidson, 1983; Denis \& Depelteau, 1985; Johanson \& Wiedersheim-Paul, 1975; Luostarinen, 1980). The internationalization process approach focuses, however, on the early steps in the internationalization process, ignoring the investment mode chosen (Kogut \& Singh, 1988).

To successfully cross national boundaries, a firm must develop information processing and control capabilities so as to coordinate activities across diverse environments, and it must develop the skills of tuning into and interpreting strategic signals specific to a foreign environment. In this process, firms unlearn practices typical of their home countries (cf. Bettis \& Prahalad, 1995; Hedberg, 1981; Lewin, 1947; McGill \& Slocum, 1993; Prahalad \& Bettis, 1986).

The complexities of working abroad are encountered not only in international joint ventures, but also in international wholly owned subsidiaries. Such subsidiaries offer firms the opportunity to learn to operate in a foreign environment incrementally, without having to simultaneously adapt to a foreign partner, thus facilitating an effective learning experience allowing for later success. Hence,

Hypothesis 1. The longevity of an international joint venture increases with the international wholly owned subsidiary experience of the firm investing abroad.

One key challenge for firms operating abroad is bridging the distance to the host culture. Cultural distance has been defined as "the sum of factors creating, on the one hand, a need for knowledge, and on the other hand, 
barriers to knowledge flow and hence also for other flows between the home and the target countries" (Luostarinen, 1980: 131-132). It has often been cited as a factor in firms' choice of less committed entry modes (Root, 1987), specifically, their preference for joint ventures over wholly owned subsidiaries (e.g. Agarwal, 1994; Bell, 1996; Bell, Barkema, \& Verbeke, 1997; Cho \& Padmanabhan, 1995; Erramilli, 1991; Erramilli \& Rao, 1993; Kogut \& Singh, 1988; Larimo, 1993; Padmanabhan \& Cho, 1996). Anderson and Gatignon (1986) noted that cultural distance caused foreign investors to avoid full ownership because distance increases information costs and difficulty in transferring management skills (Buckley \& Casson, 1976; Vachani, 1991). Cultural distance adversely affects international joint ventures by eroding the applicability of the parent's competencies (Johanson \& Vahlne, 1977; cf. Brown, Rugman, \& Verbeke, 1989; Chowdhury, 1992; Gomes-Casseres, 1989; Harrigan, 1985, 1988; Hergert \& Morris, 1988; Lorange \& Roos, 1991; Parkhe, 1991). Woodcock and Geringer (1991) argued that cultural differences produce inefficient principal-agent contracts, and Li and Guisinger (1991) found that U.S. affiliates whose partners came from culturally dissimilar countries were more likely to fail. Thus,

Hypothesis 2. The longevity of an international joint venture decreases with the cultural distance between the country of the firm investing abroad and the host country.

The need to select a partner and to cooperate and share control with the partner is a major source of complexity in joint ventures. Schaan and Beamish (1988) described the "subtle balancing act" that operating joint ventures requires. Officers at Otis, a company whose foreign venturing dates back to the 19th century, consider their firm's ability to quickly select partners and work effectively with them to be a key competitive advantage (Ingrassia, Naji, \& Rosett, 1995). According to the chairman of Corning Glass, partnering skills include "the ability to cope with the constant compromise and giveand-take that successful joint ventures require" and the ability, when necessary, to "sit back and let someone else be in the driver's seat" (Mitchell, 1988). The capacity to work with others can be learned, however, not only from previous international joint ventures, but also from previous domestic joint ventures.

That knowledge relevant to the operation of international joint ventures can be gained from domestic joint ventures is a crucial yet neglected possibility. Since the international joint venture literature is largely a product of the broader domain of international business, such ventures have been juxtaposed with other forms of foreign direct investment but not with their domestic counterparts. Yet the two joint venture types have much in common in that both facilitate the learning of partnering skills. Furthermore, domestic venturing allows a firm to learn how to cooperate without simultaneously having to deal with the complexity of a foreign environment. Thus, domestic joint ventures, like international wholly owned subsidiaries, can be a stepping stone from which to launch international joint ventures. Hence, 
Hypothesis 3. The longevity of an international joint venture increases with the previous domestic joint venture experience of the partner investing abroad.

That firms learn about international joint ventures from their previous experience with such ventures seems compelling-the experience entails exposure to both international and partnership activities. International joint venture experience has been found to increase firms' propensity to set up new ventures (Madhok, 1997), to improve their understanding of this vehicle (Lyles, 1987, 1988), and to enhance the performance of the investing firms (Mitchell, Shaver, \& Yeung, 1994) and of the investment vehicles themselves (Li, 1995). An incremental approach implies, however, that learning both partnership and boundary-crossing skills at the same time may be a task that exceeds the absorptive capacity of naive entrants who lack both types of skills. Still, we offer the following hypothesis:

Hypothesis 4. The longevity of an international joint venture increases with the previous international joint venture experience of the firm investing abroad.

\section{METHODS}

\section{Sample}

Hypotheses were tested on data on all expansions reported in the annual reports of a sample of Dutch firms between 1966 and 1994. This sample comprised the 25 largest ${ }^{1}$ Dutch companies but excluded the 4 largest (Royal Dutch, Unilever, Philips, and Akzo), which are a distinctive group in terms of their breadth of activities, international experience, scope, and size. Totals of national and international expansions during the period were 596 and 897, respectively. Of the international expansions, 244 were joint ventures.

\section{Variables}

Longevity. Following earlier research (Barkema et al., 1996; Carroll, Preisendorfer, Swaminathan, \& Wiedermayer, 1993; Carroll \& Swaminathan, 1991; Chowdhury, 1992; Li, 1995; Pennings, Barkema, \& Douma, 1994), we used longevity as the independent variable. Although it is not a perfect performance measure, previous studies have shown that longevity provides the best estimate of managers' perceptions of the success of an expansion (Geringer \& Hebert, 1991) and that it correlates with financial performance (Mitchell et al., 1994). Longevity was defined as the number of years a venture persisted. ${ }^{2}$

\footnotetext{
'In terms of firm value, these were the largest firms listed in 1994 on the Amsterdam Stock Exchange.

${ }^{2}$ Executives of a subset of 5 firms were asked to rate the success of the international joint ventures in our data set $(N=31)$ on a seven-point scale. Like Geringer and Hebert (1991), we calculated the Spearman correlation between the longevity of these international joint ventures and their success as perceived by the managers. The correlation coefficient was .55 $(p<.001)$, a value comparable to that of the coefficient found by Geringer and Hebert (.46). In addition, we found that only one of the ventures was planned to be short-lived from the start.
} 
Cultural distance. Cultural distance to the host country from the Netherlands was measured with Kogut and Singh's (1988) index. This index is an aggregate of the four dimensions of culture outlined in Hofstede (1980), and has been used often in studies of foreign entry (Agarwal \& Ramaswami, 1992; Benito \& Gripsrud, 1992; Cho \& Padmanabhan, 1995). ${ }^{3}$ Cultural difference scores unavailable from Hofstede's published work $(1980,1991)$ were obtained via personal communication with that author.

Experience. Experience with each of four types of affiliationinternational joint venture, domestic joint venture, international wholly owned subsidiary, and domestic wholly owned subsidiary-was measured as the number of previous such affiliates a firm had had by the time of a new affiliate's founding.

Control variables. To mitigate potential omitted-variable problems, we controlled for experience with domestic wholly owned subsidiaries. ${ }^{4}$ In addition, the following time-variant control variables were used: The logarithm of the assets of a firm in the year of an international joint venture's founding served as a proxy for firm size. The return on equity of the firm in that year was used as a proxy for firm profitability. We also controlled for the gross national product per capita of the host countries. Table 1 presents summary statistics on these and other variables.

\section{Analysis}

Analysis was done with LIFEREG, an event-history analysis method (SAS Institute, 1988). The model used is based on an assumed accelerated failure-time with a Weibull distribution. The analysis entailed the exploration of whether the hazard rate of ventures (the converse of the survival rate) varies with the amount and type of a firm's experience. For example, a negative coefficient associated with domestic joint venture experience implies that international joint ventures dissolve more slowly if the firm investing abroad has previous experience with domestic joint ventures.

\section{RESULTS}

Hypotheses 1 and 3 predict that international joint venture longevity increases with the experience of the firm that is investing abroad with international wholly owned subsidiaries and domestic joint ventures, respectively. Table 2 (model 1) shows that both effects are in the expected direction.

${ }^{3}$ The Kogut and Singh (1988) index of cultural distance is an arithmetic average of the deviations of each country from the index of the Netherlands along Hofstede's (1980) four cultural dimensions. Algebraically, it is calculated as $C D_{j}=\sum_{i=1,2,3,4}\left[\left(I_{i j}-I_{i n}\right)^{2} / V_{i}\right] / 4$, where $C D_{j}=$ the cultural distance of the $j$ th country from the Netherlands, $I_{i j}=$ the index for the $i$ th cultural dimension and $j$ th country, $n=$ the Netherlands, and $V_{i}=$ the variance of the index of the ith dimension.

${ }^{4}$ Firms may also benefit from other sorts of experience when launching international joint ventures - from exporting, for example-but such data were not available. If firms learn from exporting, the effects measured in this study may overestimate the effects of learning from previous international expansions on the longevity of international joint ventures. 
TABLE 1

Means, Standard Deviations, and Correlations ${ }^{a}$

\begin{tabular}{lrrrrrrrrr}
\hline \multicolumn{1}{c}{ Variable } & Mean & s.d. & $\mathbf{1}$ & $\mathbf{2}$ & $\mathbf{3}$ & $\mathbf{4}$ & $\mathbf{5}$ & $\mathbf{6}$ & $\mathbf{7}$ \\
\hline $\begin{array}{l}\text { 1. International joint } \\
\text { venture experience }\end{array}$ & 7.15 & 6.29 & & & & & & & \\
$\begin{array}{l}\text { 2. Domestic joint } \\
\text { venture experience }\end{array}$ & 3.52 & 4.67 & .25 & & & & & \\
$\begin{array}{l}\text { 3. International wholly } \\
\text { owned subsidiary }\end{array}$ & & & & & & & & \\
$\quad \begin{array}{l}\text { experience } \\
\text { 4. Domestic wholly }\end{array}$ & 13.05 & 12.61 & .50 & .34 & & & & & \\
owned subsidiary & & & & & & & & & \\
$\quad$ experience & 10.79 & 10.35 & .23 & .42 & .60 & & & & \\
$\begin{array}{l}\text { 5. Cultural distance } \\
\text { 6. Assets }\end{array}$ & 3.04 & 1.25 & .09 & .06 & .07 & -.12 & & & \\
7. Return on equity & 13.65 & 1.27 & .50 & .57 & .15 & .27 & -.05 & & \\
8. Gross national & 0.11 & 0.12 & -.20 & -.17 & .20 & .28 & -.01 & -.23 & \\
$\quad$ product & 8.52 & 6.00 & -.03 & .21 & .18 & .37 & -.27 & .17 & .14 \\
\hline
\end{tabular}

${ }^{\circ} N=244$. Correlations with absolute values greater than .13 are significant at $p<.05$.

${ }^{b}$ Value is a logarithm.

The effects of both international wholly owned subsidiary experience and domestic joint venture experience are significant $(p<.05$ and $p<.10$, respectively). Since we predicted that experience with either international wholly owned subsidiaries or domestic joint ventures could be used as a stepping stone to success with international joint ventures, we also tested a version of the model that included the interaction between international wholly owned experience and domestic joint venture experience (see model 2). If either type of experience can be used as a stepping stone, a firm that already has experience with domestic joint ventures should benefit less from experience with international wholly owned subsidiaries, and vice versa. This observation implies that the interaction term (capturing firms' having both types of experience) and the two main effects should have opposite signs. The interaction term is indeed positive and significant $(p<.01)$. The main effects of international wholly owned subsidiaries and domestic joint ventures become more significant in this model $(p<.001)$ than they were in model 1. Support for the hypotheses strengthens when the incremental nature of learning (that either type of experience can serve as a stepping stone) is recognized in the model.

Hypothesis 2 predicts that international joint venture longevity decreases with the cultural distance between foreign investor and host country. The results contained in model 1 show that the effect of cultural distance is significant and in the expected direction $(p<.05)$.

Hypothesis 4, predicting that firms benefit from previous international joint ventures when launching new ones, was not supported (see Table 2). Apparently, the firms in our sample did not learn from their previous international joint venture experience. 


\section{AM丁 14732 TABLE 2}

\section{Results of Event-History Analysis for Types of Experience ${ }^{a}$}

\begin{tabular}{lcc}
\hline \multicolumn{1}{c}{ Independent Variables } & Model 1 & Model 2 \\
\hline Intercept & 0.87 & 0.59 \\
& $(1.15)$ & $(1.22)$ \\
International joint venture experience & 0.01 & 0.03 \\
& $(0.03)$ & $(0.03)$ \\
Domestic joint venture experience & $-0.05+$ & $-0.19^{\star * *}$ \\
& $(0.03)$ & $(0.06)$ \\
International wholly owned subsidiary experience & $-0.03^{\star}$ & $-0.06^{\star \star *}$ \\
& $(0.02)$ & $(0.02)$ \\
Domestic wholly owned subsidiary experience & 0.01 & -0.00 \\
& $(0.01)$ & $(0.01)$ \\
Domestic joint venture $\times$ international wholly owned subsidiary & & $0.01^{\star \star}$ \\
experience & & $(0.00)$ \\
Cultural distance & $0.12^{\star}$ & $0.13^{*}$ \\
Assets & $(0.07)$ & $(0.07)$ \\
& 0.14 & $0.18+$ \\
Return on equity & $(0.09)$ & $(0.09)$ \\
& $1.55+$ & 1.15 \\
Gross national product per capita & $(0.86)$ & $(0.86)$ \\
Log likelihood & -0.01 & -0.01 \\
& $(0.01)$ & $(0.02)$ \\
\hline
\end{tabular}

a Numbers in parentheses are standard deviations.

${ }^{b}$ Value is a logarithm.

$+p<.10$

${ }^{\star} p<.05$

${ }^{* *} p<.01$

$\star \star \star p<.001$

\section{Product Diversification as a Moderator}

A key notion underlying this research is that firms can only absorb experience if it relates to what they already know (Cohen \& Levinthal, 1990). International expansion paths need to be incremental to allow firms to interpret new experience and to foster learning. This statement suggests that a firm learns from experience with international wholly owned subsidiaries and with domestic joint ventures if the experience is related to the firm's knowledge base-if it is acquired in the same line of business as the firm's principal business (constituting horizontal expansion), or in a related line of business (related expansion), or up or down the value chain (vertical expansion). In contrast, expansion into an unrelated line of business may trigger information overload and make it difficult for a firm's key managers to interpret the experience and benefit from it when entering international joint ventures later.

The sampled firms' expansion experience was thus separated into (1) horizontal, related, and vertical expansions (cf. Pennings et al., 1994) and 
(2) unrelated expansions. Table 3 presents the estimation results, which show significant effects for both experience with international wholly owned subsidiaries and experience with domestic joint ventures in related businesses. The effects of previous experience in unrelated businesses are insignificant. The results are again consistent with an incremental learning approach.

\section{Sensitivity Analysis}

Firm-specific effects. In view of Hitt, Harrison, Ireland, and Best's (1995) findings for mergers and acquisitions, we also considered learning effects at

TABLE 3

Results of Event-History Analysis with Product Diversification as Moderator ${ }^{\mathrm{a}}$

\begin{tabular}{lc}
\hline \multicolumn{1}{c}{ Independent Variables } & Model 3 \\
\hline Intercept & 0.46 \\
& $(1.37)$ \\
Unrelated international joint venture experience & 0.02 \\
& $(0.09)$ \\
Related international joint venture experience & 0.03 \\
& $(0.04)$ \\
Unrelated domestic joint venture experience & -0.13 \\
Related domestic joint venture experience & $(0.13)$ \\
& $-0.20^{*}$ \\
Unrelated international wholly owned subsidiary experience & $(0.09)$ \\
& -0.07 \\
Related international wholly owned subsidiary experience & $(0.12)$ \\
& $-0.05^{\star}$ \\
Domestic wholly owned subsidiary experience & $(0.03)$ \\
& -0.00 \\
Unrelated domestic joint venture $\times$ international wholly owned subsidiary & $(0.01)$ \\
experience & -0.03 \\
Unrelated domestic joint venture $\times$ related international wholly owned & $(0.12)$ \\
subsidiary experience & 0.00 \\
Related domestic joint venture $\times$ unrelated international wholly owned & $(0.01)$ \\
subsidiary experience & 0.04 \\
Related domestic joint venture $\times$ related international wholly owned subsidiary & $(0.09)$ \\
experience & $0.02^{\star}$ \\
Cultural distance & $(0.01)$ \\
& $0.13^{*}$ \\
Assets & \\
Return on equity & $(0.07)$ \\
Gross national product per capita & 0.18 \\
& $(0.10)$ \\
Log likelihood & 1.77 \\
\hline & $(1.07)$ \\
& -0.01 \\
& $(0.02)$ \\
& -188 \\
\hline
\end{tabular}

"Numbers in parentheses are standard deviations.

balue is a logarithm.

${ }^{\star} p<.05$ 
the individual firm level, using models with interactions between learning effects and dummy variables for firm. This procedure captured firm-specific learning gained from previous types of affiliation and applied to new international joint ventures. Not all 25 firms had engaged in all the affiliate types studied, so fewer than 25 interaction terms resulted for each type of learning effect. In addition, some interaction terms had to be removed from the models for reasons of multicollinearity. There remained 17 firm-specific effects of previous international wholly owned subsidiaries, 13 firm-specific effects of previous domestic joint ventures, and 16 firm-specific effects of previous international joint ventures. Of these effects, 11,10 , and 5 , respectively, were significant and in the expected direction, mostly at the $p<.001$ level. The results suggest that most firms learned about international joint ventures from international wholly owned subsidiaries or domestic joint ventures and that some firms also learned from previous international joint ventures. A subsequent analysis suggested that firms did not learn from previous international joint ventures unless the latter experience was preceded by experience with either domestic joint ventures or with international wholly owned subsidiaries. ${ }^{5}$ Finally, an exploratory analysis suggested that firms learned from failures rather than successes with international wholly owned subsidiaries, but this result was not obtained for domestic joint venture experience.

Shape of experience curves. To examine learning theory's assertion regarding decreasing marginal returns from experience (Yelle, 1979), we added quadratic terms of the experience variables to the linear effects. The quadratic effects were insignificant. We also estimated models that separated the experience with international wholly owned subsidiaries into two categories, experience with fewer than 10 international wholly owned subsidiaries, and experience with more than 10 . We also estimated similar models for two categories of domestic joint venture experience and international joint venture experience, respectively. The analyses did not support the notion of decreasing returns to learning. ${ }^{6}$ Learning about international joint ventures may be so complex that the experience curve had not leveled off yet for the firms studied, which were in their early decades of international expansion.

Hofstede's dimensions. Culture is a complex phenomenon that embodies a host of values, beliefs, and norms, many of which are subtle, intangible, and difficult to measure. Interpretation of culture as a unidimensional, aggregate phenomenon, although popular in the foreign entry literature (e.g., Agarwal \& Ramaswami, 1992), oversimplifies a complex construct (Shenkar \& Zeira, 1992) and may explain the mixed results studies have yielded regarding the

${ }^{5}$ We found no significant learning effects of previous international joint ventures that were not preceded by international wholly owned subsidiaries or domestic joint ventures. Exploratory analysis revealed a significant learning effect of international joint ventures preceded by at least 10 domestic joint ventures or 30 international wholly owned subsidiaries. The effect remained if firm dummies were added to the analysis.

${ }^{6}$ Similar conclusions were reached for other cut-off rates, for instance, for 5 and for 20 ventures. 
impact of cultural distance on foreign expansion (Benito \& Gripsrud, 1992; Kogut \& Singh, 1988; Madhok, 1997; Padmanabhan \& Cho, 1996).

To take account of this complexity, we did some further analysis regarding Hofstede's conjectures about the different impacts of gaps between two cultures along his four dimensions. Hofstede (1989) suggested that although some cultural gaps were not very disruptive or were even complementary, differences between two cultures in uncertainty avoidance were potentially very problematic for international cooperation because of correlated differences in tolerance toward risk, formalization, and the like. An uncertainty avoidance gap is likely to be detrimental to international joint venture operation because uncertainty is an inherent characteristic of operating in a foreign environment and because such a gap implies contrasting expectations regarding the predictability of partner behavior, also a key issue in international joint ventures. Indeed, the results show a significant effect for uncertainty avoidance $(0.19, p<.01)$ but not for the other dimensions. ${ }^{\text {? }}$

Developed versus developing countries. Experience with international wholly owned subsidiaries in developed countries may be less useful when applied to joint ventures in developing countries, and vice versa. Hence, experience with international wholly owned subsidiaries was separated into experience in developed countries (Ronen and Shenkar's [1985] Nordic, Germanic, Anglo, and Latin European blocs) and in developing countries (the remaining Ronen and Shenkar blocs; see Table 4). The dummy variable "developed country" in Table 4 captures whether an international joint venture was in a developed country (or not), and the dummy variable "developing country" captures the opposite.

The results presented in Table 4 show that international joint ventures in developed countries benefit significantly from the experience of the firms investing abroad (the Dutch firms) with international wholly owned subsidiaries in developed countries, but not from such firms' previous ventures in developing countries. Similarly, international joint ventures in developing countries benefit significantly from investor's previous experience with international wholly owned subsidiaries in developing countries, but not from experience with such subsidiaries in developed countries.

Another interesting result given in Table 4 is that the effect of cultural distance is significant for international joint ventures in developing countries, but not for international joint ventures in developed countries. To get a sharper view of the effects of cultural differences between the foreign and host country on the longevity of international joint ventures in developed countries, we replaced the cultural distance variable (per Hofstede) for developed countries with dummy variables representing Ronen and Shenkar's blocs, making the Nordic bloc (to which the Netherlands belongs) the omitted

${ }^{7}$ No effects were found for the power distance and masculinity/femininity dimensions. The effect of individualism became significant if gross national product per capita was deleted from the model as a control variable. 
Results of Event-History Analysis for Developed/Developing Countries ${ }^{a}$

\begin{tabular}{lc}
\hline \multicolumn{1}{c}{ Independent Variables } & Model 4 \\
\hline Intercept & 1.71 \\
& $(1.31)$ \\
International joint venture experience & 0.05 \\
& $(0.04)$ \\
Domestic joint venture experience & $-0.15^{\star *}$ \\
& $(0.06)$ \\
Developed international wholly owned subsidiary experience $\times$ developed & $-0.07^{\star *}$ \\
country & $(0.02)$ \\
Developed international wholly owned subsidiary experience $\times$ developing & -0.01 \\
country & $(0.03)$ \\
Developing international wholly owned subsidiary experience $\times$ developed & -0.02 \\
country & $(0.12)$ \\
Developing international wholly owned subsidiary experience $\times$ developing & $-0.11^{\star \star \star}$ \\
country & $(0.03)$ \\
Domestic wholly owned subsidiary experience & -0.01 \\
& $(0.01)$ \\
Domestic joint venture $\times$ international wholly owned subsidiary experience & $0.01^{\star}$ \\
Cultural distance $\times$ developed country & $(0.01)$ \\
& 0.03 \\
Cultural distance $\times$ developing country & $(0.11)$ \\
& $0.14^{*}$ \\
Assets & $(0.07)$ \\
Return on equity & 0.08 \\
Gross national product per capita & $(0.10)$ \\
& $2.09^{*}$ \\
Log likelihood & $(1.05)$ \\
\hline
\end{tabular}

${ }^{*} p<.05$

${ }^{* *} p<.01$

$* * * p<.001$

" Numbers in parentheses are standard deviations.

${ }^{b}$ Value is a logarithm.

category. ${ }^{8}$ The results showed significant effects for the Germanic, Anglo, and Latin European dummies (1.46, $p<.05,1.67, p<.05$, and 1.55, $p<$ .05 , respectively), suggesting that joint ventures of Dutch companies with partmers in the three latter blocks encountered more problems than Dutch ventures with partners from other Nordic block countries. Using any of the other three dummies (Germanic, Anglo, or Latin European) as the omitted

'The Ronen and Shenkar (1985) cultural blocs are based on a synthesis of eight clustering studies, including Hofstede (1980). The clustering represents the similarity of national cultures and transcends the explicit dimensions making up that complex construct. 
category did not result in significant effects for the other two, suggesting that the magnitude of cultural problems did not vary significantly across these three cultural blocs. ${ }^{9}$

Further analyses. In further analyses, a number of control variables were added, including a time-variant measure of firm diversification (capturing the level of diversification for each firm for each year) and the level of diversification implied by the international joint venture (coded 1 for related, horizontal, or vertical diversification and 0 otherwise). These analyses did not lead to different conclusions. We also separated previous experience with international wholly owned subsidiaries into experience with start-ups and experience with acquisitions and obtained virtually identical results for both. Finally, we repeated all the analyses using distributions other than the Weibull distribution that underpins the above results, including gamma, logarithmic logistic, and logarithmic normal distributions. All the results were equally supportive.

\section{DISCUSSION}

The findings of the present study expand earlier findings illustrating the incremental nature of firms' learning of new technologies (Cohen \& Levinthal, 1990), across industries (Chang, 1995; Pennings et al., 1994; Ramanujam \& Varadarajan, 1989), and beyond national borders (Barkema et al., 1996; Johanson \& Vahlne, 1977; Johanson \& Wiedersheim-Paul, 1975). Specifically, this study identifies both experience with domestic joint ventures and experience with international wholly owned subsidiaries as stepping stones from which operation of international joint ventures can be successfully launched-as long as the experience is related to a firm's core business. Domestic joint ventures allow firms to learn about partnering without having to simultaneously handle the vagaries of foreign settings. International wholly owned subsidiaries allow firms to learn how to operate in foreign settings without the complexities of cooperating with a partner, provided the experience is accumulated in the same context-that is, in developed countries if the new expansion is into a developed country, and in developing countries if the new expansion is into a developing country. And, in line with previous conjectures (e.g., Hofstede, 1989), international joint venture longevity decreased with the cultural distance between a Dutch investor and a host country.

The significant role played by domestic joint ventures in preparing firms for cross-border joint ventures is especially noteworthy and represents a unique contribution of this research. In addition to pinpointing a crucial, yet neglected, way of learning to successfully operate international joint ventures,

\footnotetext{
${ }^{9}$ Not surprisingly, estimation results from the full model with dummies for all Ronen and Shenkar blocs (Germanic, Anglo, Latin European, Latin American, Far Eastern, African, etc., with Nordic as the omitted category) tested on the whole data set showed highly significant effects of the bloc dummies associated with non-European cultures.
} 
this finding has implications for the learning process in international business. The finding confirms that an analysis of a multinational corporation's operations abroad should also include paths from its domestic activities, and that international business research should not be rigidly confined to nondomestic operations.

If one accepts the premise that the national culture of a multinational corporation can moderate its ability to learn to cooperate with others and to adapt to foreign settings (Hickson, 1996; Hofstede, 1983), the present study - which was limited to Dutch multinationals-should be replicated for firms rooted in other national settings. Given our confirmation of the importance of uncertainty avoidance (Hofstede, 1989), it would be interesting to compare the findings for the Netherlands, a country with low uncertainty avoidance, with results for a country with high uncertainty avoidance, such as Japan. Similarly, given the prominence of the Netherlands as a foreign investor, multinational corporations from developing and newly industrialized economies would make a valuable base for comparison.

The above strategies, combined with the broadening of potential learning paths to include trading activities as well as mergers and acquisitions, will go a long way toward enhancing scholars' understanding of the foreign investment learning process. This understanding will not be complete, however, without injecting the internal processes that are part and parcel of the learning process. The present findings suggest that most, but not all, firms benefit from their experience with domestic joint ventures and international wholly owned subsidiaries when entering international joint ventures. To understand why, researchers should examine the structural and process factors facilitating learning in alliances (cf. Hitt et al., 1995), as well as the customized channels allowing for the creation and transfer of knowledge within multinational corporations (cf. Bartlett \& Ghoshal, 1989; Hedlund, 1994).

\section{REFERENCES}

Agarwal, S. 1994. Socio-cultural distance and the choice of joint ventures: A contingency perspective. Journal of International Marketing, 2: 63-80.

Agarwal, S., \& Ramaswami, S. N. 1992. Choice of organizational form in foreign markets: A transaction cost perspective. Paper presented at the annual meeting of the Academy of International Business, Brussels.

Anderson, E., \& Gatignon, H. 1986. Modes of foreign entry: A transaction cost analysis and propositions. Journal of International Business Studies, 17: 1-26.

Barkema, H. G., Bell, J. H. J., \& Pennings, J. M. 1996. Foreign entry, cultural barriers, and learning. Strategic Management Journal, 17: 151-166.

Bartlett, C. A., \& Ghoshal, S. 1989. Managing across borders: The transnational solution. London: Hutchinson Business Books.

Bell, J. H. J. 1996. Single or joint venturing? A comprehensive approach to foreign entry mode choice. Aldershot, England: Avebury.

Bell, J. H. J., Barkema, H. G., \& Verbeke, A. 1997. An eclectic model of the choice between WOS s and JVs as modes of foreign entry. In P. W. Beamish \& J. P. Killing (Eds.), Cooperative strategies: European perspectives: Forthcoming. San Francisco: New Lexington. 
Benito, C. R. G., \& Gripsrud, G. 1992. The expansion of foreign direct investments: Discrete rational location choices or a cultural learning process? Journal of International Business Studies, 23: 461-476.

Berg, S. V., Duncan, J. L., Jr., \& Friedman, P. 1982. Joint venture strategies and corporate innovation. Cambridge, MA: Oelschlager, Gunn \& Hain.

Bettis, R. A., \& Prahalad, C. K. 1995. The dominant logic: Retrospective and extension. Strategic Management Journal, 16: 5-14.

Brown, L. T., Rugman, A. M., \& Verbeke, A. 1989. Japanese joint ventures with western multinationals: Synthesising the economic and cultural explanations of failure. Asia Pacific Journal of Management, 6: 225-242.

Buckley, P. J., \& Casson, M. 1976. The future of the multinational enterprise. London: MacMillan.

Buckley, P. J., \& Casson, M. 1988. A theory of cooperation in international business. In F. J. Contractor \& P. Lorange (Eds.), Cooperative strategies in international business: 31-55. Lexington, MA: Lexington Books.

Carroll, G. R., Preisendorfer, P., Swaminathan, A., \& Wiedenmayer, G. 1993. Brewery and brauerei: The organizational ecology of brewing. Organization Studies, 14: 155-188.

Carroll, G. R., \& Swaminathan, A. 1991. Density dependent organizational evolution in the American brewing industry from 1633 to 1988. Acta Sociologica, 34: 155-175.

Chang, S. J. 1995. International expansion strategy of Japanese firms: Capability building through sequential entry. Academy of Management Journal, 38: 383-407.

Cho, K. R., \& Padmanabhan, P. 1995. Acquisition versus new venture: The choice of foreign establishment mode by Japanese firms. Journal of International Management, 1: 255-285.

Chowdhury, J. 1992. Performance of international joint ventures and wholly owned foreign subsidiaries: A comparative perspective. Management International Review, 32: 115-133.

Cohen, W. M., \& Levinthal, D. A. 1989. Innovation and learning: The two faces of R\&D. Economic Journal, 99: 569-596.

Cohen, W. M., \& Levinthal, D. A. 1990. Absorptive capacity: A new perspective on learning and innovation. Administrative Science Quarterly, 35: 128-152.

Cohen, W. M., \& Levinthal, D. A. 1994. Fortune favors the prepared firm. Management Science, 40: 227-251.

Contractor, F. J., \& Lorange, P. 1988. Why should firms cooperate? The strategy and economics basis for cooperative ventures. In F. J. Contractor \& P. Lorange (Eds.), Cooperative strategies in international business: 3-30. Lexington, MA: Lexington Books.

Cyert, R. M., \& March J. G. 1963. A behavioral theory of the firm. Englewood Cliffs, NJ: Prentice-Hall.

Davidson, W. H. 1983. Market similarity and market selection: Implications of international marketing strategy. Journal of Business Research, 11: 439-456.

Denis, J. E., \& Depelteau, D. 1985. Market knowledge, diversification and export expansion. Journal of International Business Studies, 16: 77-89.

Erramilli, M. K. 1991. The experience factor in foreign market entry behavior of service firms. Journal of International Business Studies, 22: 479-501.

Erramilli, M. K., \& Rao, C. P. 1993. Service firms' international entry mode choice: A modified transaction-cost analysis approach. Journal of Marketing, 57(3): 19-38.

Gatignon, H., \& Anderson, E. 1988. The multinational corporation's degree of control over foreign subsidiaries: An empirical test of a transaction cost explanation. Journal of Law, Economics, and Organization, 4: 305-336. 
Geringer, J. M., \& Hebert, L. 1991. Measuring performance of international joint ventures. Journal of International Business Studies, 22: 249-263.

Gomes-Casseres, B. 1987. Joint venture instability: Is it a problem? Columbia Journal of World Business, 22(2): 97-102.

Gomes-Casseres, B. 1989. Ownership structures of foreign subsidiaries: Theory and evidence. Journal of Economic Behavior and Organization, 11: 1-25.

Harrigan, K. R. 1985. Strategies for joint ventures. Lexington, MA: Lexington Books.

Harrigan, K. R. 1988. Strategic alliances and partner asymmetries. In F. J. Contractor \& P. Lorange (Eds.), Cooperative strategies in international business. Lexington, MA: 205-226. Lexington Books.

Hedberg, B. 1981. How organizations learn and unlearn. In P. C. Nystrom \& W. H. Starbuck (Eds.), Handbook of organizational design: 3-27. London: Oxford University Press.

Hedlund, G. 1994. A model of knowledge management and the N-form corporation. Strategic Management Journal, 15: 73-90.

Hennart, J-F. 1988. A transaction cost theory of equity joint ventures. Strategic Management Journal, 9: 361-374.

Hennart, J-F. 1991. The transaction costs theory of joint ventures: An empirical study of Japanese subsidiaries in the United States. Management Science, 37: 483-497.

Hergert, M., \& Morris, D. 1988. Trends in international collaborative agreements. In F. J. Contractor \& P. Lorange (Eds.), Cooperative strategies in international business: 99-110. Lexington, MA: Lexington Books.

Hickson, D. J. 1996. The ASQ years then and now through the eyes of a Euro-Brit. Administrative Science Quarterly, 41: 217-228.

Hill, R. C., \& Hellriegel, D. 1994. Critical contingencies in joint venture management: Some lessons from managers. Organization Science, 5: 594-607.

Hitt, M. A., Harrison, J. S., Ireland, R. D., \& Best, A. 1995. Learning how to dance with the Tasmanian devil: Understanding acquisition success and failure. Paper presented the annual meeting of the Strategic Management Society, Mexico City.

Hofstede, G. 1980. Culture's consequences: International differences in work-related values. Beverly Hills, CA: Sage.

Hofstede, G. 1983. The cultural relativity of organizational practices and theories. Journal of International Business Studies, 2: 75-89.

Hofstede, G. 1989. Organising for cultural diversity. European Management Journal, 7: 390-397.

Hofstede, G. 1991. Cultures and organizations: Software of the mind. Berkshire, England: McGraw-Hill.

Ingrassia, L., Naji, A. K., \& Rosett, C. 1995. Overseas, Otis and its parent get in on the ground floor. Wall Street Journal, April 21: A8.

Johanson, J., \& Vahlne, J. E. 1977. The internationalization process of the firm: A model of knowledge development and increasing foreign market commitments. Journal of International Business Studies, 8: 23-32.

Johanson, J., \& Wiedersheim-Paul, F. 1975. The internationalization of the firm: Four Swedish cases. Journal of Management Studies, 12: 305-322.

Kogut, B. 1988. Joint ventures: Theoretical and empirical perspectives. Strategic Management Journal, 9: 319-332. 
Kogut, B., \& Singh, H. 1988. The effect of national culture on the choice of entry mode. Journal of International Business Studies, 19: 411-432.

Larimo, J. 1993. Foreign direct investment behaviour and performance: An analysis of Finnish direct manufacturing investments in OECD countries. Acta Wasaensia, no. 32. Vaasa, Finland: University of Vaasa.

Levine, J. B., \& Byrne, J. A. 1986. Corporate odd couples. Business Week, July 21: 100-105.

Lewin, K. 1947. Frontiers in group dynamics: Concepts, method, and reality in social science. Human Relations, 1: 5-41.

Li, J. T. 1995. Foreign entry and survival: Effects of strategic choices on performance in international markets. Strategic Management Journal, 16: 333-351.

Li, J. T., \& Guisinger, S. 1991. Comparative business failures of foreign-controlled firms in the United States. Journal of International Business Studies, 22: 209-224.

Lorange, P., \& Roos, J. 1991. Why some strategic alliances succeed and others fail. Journal of Business Strategy, 12(1): 25-30.

Luostarinen, R. 1980. Internationalization of the firm. Helsinki: Helsinki School of Economics.

Lyles, M. 1987. Common mistakes of joint venture experienced firms. Columbia Journal of World Business, 22(2): 79-85.

Lyles, M. A. 1988. Learning among joint venture-sophisticated firms. In F. J. Contractor \& P. Lorange (Eds.), Cooperative strategies in international business. 301-316. Lexington, MA: Lexington Books.

Madhok, A. 1997: Cost, value and foreign market entry mode: The transaction and the firm. Strategic Management Journal, 18: 39-61.

McGill, M. E. \& Slocum, J. W., Jr. 1993. Unlearning the organization. Organizational Dynamics, 22(2): 67-79.

Mitchell, C. 1988. Partnerships have become a way of life for Corning. Wall Street Journal, July 12.

Mitchell, W., Shaver, J. M., \& Yeung, B. 1994. Foreign entrant survival and foreign market share: Canadian companies' experience in United States medical sector markets. Strategic Management Journal, 15: 555-567.

Padmanabhan, P., Cho, K. R. 1996. Ownership strategy for a foreign affiliate: An empirical investigation of Japanese firms. Management International Review, 36: 45-65.

Parkhe, A. 1991. Interfirm diversity, organizational learning, and longevity in global strategic alliances. Journal of International Business Studies, 22: 579-600.

Pennings, J. M., Barkema, H. G., \& Douma, S. W. 1994. Organizational learning and diversification. Academy of Management Journal, 37: 608-640.

Prahalad, C. K., Bettis, R. A. 1986. The dominant logic: A new linkage between diversity and performance. Strategic Management Journal, 7: 485-501.

Ramanujam, V., \& Varadarajan, P. 1989. Research on corporate diversification: A synthesis. Strategic Management Journal, 10: 523-551.

Ronen, S., \& Shenkar, O. 1985. Clustering countries on attitudinal dimensions: A review and synthesis. Academy of Management Review, 10: 435-454.

Root, F. 1987. Entry strategies for international markets. Lexington, MA: Lexington.

SAS Institute. 1988. SAS users guide: Statistics. Durham, NC: SAS Institute.

Schaan, J. L., \& Beamish, P. 1988. Joint venture general managers in LDCs. In F. J. Contractor \& Lorange, P. (Eds.), Cooperative strategies in international business: 279-299. Lexington, MA: Lexington Books. 
Shenkar, O., \& Zeira, Y. 1987. Human resources management in international joint ventures: Directions for research. Academy of Management Review, 12: 546-557.

Shenkar, O., \& Zeira, Y. 1992. Role conflict and role ambiguity of chief executive officers in international joint ventures. Journal of International Business Studies, 23: 55-75.

Stopford, J. M., \& Wells, L. T., Jr. 1972. Managing the multinational enterprise: Organisation of the firm and ownership of the subsidiaries. New York: Basic Books.

Vachani, S. 1991. Distinguishing between related and unrelated international geographic diversification: A comprehensive measure of global diversification. Journal of International Business Studies, 22: 307-322.

Woodcock, C. P., \& Geringer, M. J. 1991. An exploratory study of agency costs related to the control structure of multi-partner, international joint ventures. Academy of Management Best Papers Proceedings: 115-118.

Wysocki, B. 1990. Cross-border alliances become favorite way to crack new markets. Wall Street Journal, March 26: A1.

Yelle, L. E. 1979. The learning curve: Historical review and comprehensive survey. Decision Sciences, 10: 302-328.

Harry G. Barkema (Ph. D., Groningen University) is a professor of international management and the director of the Center for International Management Studies at Tilburg University. His current research focuses on organizational learning, foreign entry, and executive compensation.

Oded Shenkar (Ph.D., Columbia University) is a professor in and the director of the international business program at Tel-Aviv University and a professor of management at the University of Hawaii-Manoa. His current research focuses on international strategic alliances and Chinese managerial reforms.

Freek Vermeulen is a doctoral candidate in organization and strategy at Tilburg University. His research focuses on organizational learning and capabilities in foreign direct investment.

John H. J. Bell (Ph.D., Tilburg University) is an assistant professor of organization and strategy at Tilburg University. His research interests include entry modes, interfirm relationships (e.g., joint ventures, strategic alliances, networks), international management, and strategic decision making. 
Copyright of Academy of Management Journal is the property of Academy of Management and its content may not be copied or emailed to multiple sites or posted to a listserv without the copyright holder's express written permission. However, users may print, download, or email articles for individual use. 